\title{
Polyzoa opuntia (Ascidiacea) in the Magellan Region, Chile: Colony shape changing with size and substrate
}

\author{
Polyzoa opuntia (Ascidiacea) en la región de Magallanes, Chile: \\ Forma colonial cambia con el tamaño y tipo de sustrato
}

Juan I. Cañete ${ }^{1}$

The discovery of large colonial ascidians remain as unusual or striking fact (Ramos-Esplá \& Ocaña, 2017). Morphotypes of elongated colonies has been cited in some ascidians families such as Didemnidae and Holozoidae (Millar, 1971; Monniot et al. 1991), with most singular case in Distaplia cylindrica from Antarctic waters which can reach to $7 \mathrm{~m}$ of length (Kott, 1969). Other reports shown colonies of Eudistoma elongatum (Herdman, 1886), Distaplia cylindrica (Lesson, 1830) and Aplidium proliferum (Milne Edwards, 1841) attaining to $2,5 \mathrm{~m}$ lenght (Page \& Kelly, 2013; Ramos-Esplá \& Ocaña, 2017). These species shown colonies elongated to cylindrical shape with form of drop or tears (Biosecurity New Zealand, 2007).

In E. elongatum there is a seasonal pattern in the colonial growth where the colonies regress and over-winter as small (c. $10 \mathrm{~mm}$ ) cream buds and re-growing the following spring to larger colonies (Page \& Kelly, 2013). Fast growth produce didemnid colonies of great size, extending over more than a square meter when the substrate is large enough. However, this colonies are encrusting (Monniot et al. 1991).

Some patagonian specimens of Polyzoa opuntia has been sized as large as $15 \mathrm{~cm}$ of length in some Chilean fjords (Tatián \& Lagger, 2009). Others Chilean populations of Polyzoa opuntia form colonies of $10 \mathrm{~cm}$ or more in extent, comprising numerous zooids averaging about $10 \mathrm{~mm}$ height and $4 \mathrm{~mm}$ diameter. Zooids are typically cylindrical and connected by a basal test only (Turon et al. 2016b). However, these colonies are usually found on thin elongated objects, such as polychaete tubes, shells of bivalves or branches. The body wall of zooids removed from their test is muscular and thick.

The present study have as goals to report the presence of giant colonies in relation to previous studies of the ascidians $P$. opuntia in some locations of the Magellan Region, to show changes of colonial shape with size as with substrate as well as to describe the weight-length relationship in this colonial species. The large abundance and large size of colonies could produce problemas of biosecurity and fouling in aquaculture, in coastal building and in equipments disposed in Antarctic and Magellan Subantarctic areas (Biosecurity New Zealand, 2007).

Some colonies were collected during September, 2013 (Turon et al. 2016a, 2016b), which were used mainly to analyse the change of colonial shape with size around Punta Arenas (Cabo Negro Cape and Santa Ana Point), Magellan Strait, Chile. Other samples were collected between September to December of 2016 in Porvenir Bay, Punta Arenas and Puerto Williams, Beagle Channel, respectively (Table 1) and were surveyed by SCUBA diving or by pulling up ropes and collecting directly from pier or docks. Other colonies were collected during November, 2018, in an intertidal fringe fixed of a stranded ship (MV Magallanes III)

\footnotetext{
1 Facultad Ciencias, Universidad de Magallanes,

Punta Arenas, Chile

$\measuredangle$ ivan.canete@umag.cl
} 
located in the sandy beach off Catalina Bay, Punta Arenas (Table 1). At each site, the colonies were randomly collected from artificial (docks, pilings, piers, aquaculture facilities) and natural substratum (shell of Mytilus spp; four species are reported in Magellan waters; Oyarzún et al. 2016). Sampling was exhaustive (i.e., typically, surveys lasted ca. 1 $\mathrm{hr}$ of diving and the depths studied ranged from 2 to $4 \mathrm{~m})$. Surface temperature of sea water was recorded with a digital thermometer $\left( \pm 0,1^{\circ} \mathrm{C}\right)$ in both locations; salinity and dissolved oxygen were previosuly recorded in Porvenir Bay, showing estuarine and oxygenated condition along the year (Cañete et al. 2014).

Ascidians were photographed in vivo, carefully collected in Ziploc bags, and brought to the laboratory as soon as possible (within 2 hrs after collection). Ascidians were placed in trays and relaxed with a combination of menthol (adding 1 or $2 \mathrm{ml}$ of saturated menthol solution) and a cold treatment (keeping the trays in a freezer until ice formed on the surface).

Colonies were classified in three morphological patterns, which was related to the size: small were rounded, mid size with drop shape and the largest colonies were cylindrical and longest colonies. Colonies were counted according to shape pattern to estimate the frequency and each measured in the largest axe.

Total weight and length measurements were based on relaxed colonies collected in 2016 and 2018 ( $N=104$ ), considering all morphological pattern. All were dryed to the air during 10 minutes to eliminate remanent of water, weighted and recording the complete colony diameter (small colonies) or the total length (large colonies) using a common ruler, respectively. Samples were then split for preservation: most of the material was fixed in formaldehyde $4 \%$ for morphological observation. Ascidians were identified to species level using relevant literature (Sanamyan et al. 2003; Turon et al. 2016a, b). Taxonomy followed the guidelines of the World Register of Marine Species (Shenkar et al. 2017).

Specimens preserved in formaldehyde were deposited in the Systematic Room, Instituto de la Patagonia, Universidad de Magallanes, Punta Arenas, Chile (SRIP-UMAG, Codes 2927900178).
This study considered the analysis of 104 colonies for morphological and quatitative analysis. Three morphological patterns were observed, according to the size: a) small colonies, with rounded shape, with 1 to $15 \mathrm{~cm}$ of diameter (55\%) (Fig. 1a; Fig. 2), b) medium size colonies collected under a stranded, old boat from Puerto Williams, Navarino Island, Chile, which showing shaped drops colonies. This shape was observed in colonies vertically attached from subtrata (31\%) (Fig. 1b; Fig. 2); similar shape was observed in colonies collected in a stranded ship from Catalina Bay, and c) elongated colonies, shaped cylindrical (between 80 to $240 \mathrm{~cm}$ ) were uncommon (14\%) (Fig. 1c-f) (Table 1; Fig. 2).

Cylindrical colonies were collected during September, 2016 in Chilota dock, Porvenir Bay, showing a total length of $240 \mathrm{~cm}$ and a weight of $440 \mathrm{~g}$ (Table 1). These colonies were observed floating in the water column in paralell position respect to the sea bed (Fig. 1f). The holdfast of colonies are smallest in relation to the rest of the colony; in the largest colony, the holdfast and peduncle have a length of $8 \mathrm{~cm}$ (Fig. 1d), while the rest of colony showing $232 \mathrm{~cm}$ of length. Other colonies of similar shape measuring between 100 to $180 \mathrm{~cm}$ of length (Fig. 2).

The vertically disposed colonies ranged from 15 to $100 \mathrm{~cm}$ in length, with a drop shape. In the specimens collected in Catalina Bay (Fig. 1g-i), the peduncle have similar length that the colony and small, gregarious buds were observed along of distal end.

The globular colonies were collected during September, 2013, showing gregariousness behaviour and settled on living Mytilus spp. shells suspended in the water column (Fig. 1 a).

There is a significant, positive, linear relationship between total length and weight in the colonies of $P$. opuntia. Colonies of $300 \mathrm{~cm}$ of length could attain a total weight of $500 \mathrm{~g}$ (Fig. 2). We collect some colonies smallest than $1 \mathrm{~cm}$ of diameter with globular shape. After $15 \mathrm{~cm}$, the colonies attain a shaped drops (Fig. 1). The width of cylindrical colonies varied from 0.5 to $5 \mathrm{~cm}$ of diameter.

The main results of this study demonstrate a wide polymorphism in the P. opuntia colonies, the shape of colonies changing with size and the 
Table 1. Locations of Magellan Region, Chile, where colonies of the ascidian Polyzoa opuntia where collected to study the relation between size and shape. Total length and weight are expressed as range (n.d.: no data).

\begin{tabular}{|c|c|c|c|c|c|c|}
\hline \multirow[b]{2}{*}{ Parameters } & \multicolumn{6}{|c|}{ Locations } \\
\hline & $\begin{array}{l}\text { Chilota dock, } \\
\text { Porvenir Bay, } \\
\text { Tierra del Fuego }\end{array}$ & $\begin{array}{l}\text { Arturo Prat dock, } \\
\text { Punta Arenas }\end{array}$ & $\begin{array}{c}\text { Cabo Negro } \\
\text { dock, Pelicano } \\
\text { Bay }\end{array}$ & $\begin{array}{l}\text { Chilota dock, } \\
\text { Porvenir Bay, } \\
\text { Tierra del Fuego } \\
\text { Island }\end{array}$ & $\begin{array}{c}\text { Micalvi } \\
\text { Pontoon, } \\
\text { Puerto } \\
\text { Williams, } \\
\text { Navarino Island }\end{array}$ & $\begin{array}{c}\text { MN Magallanes III } \\
\text { Catalina Bay } \\
\text { Punta Arenas }\end{array}$ \\
\hline $\begin{array}{l}\text { Type of } \\
\text { subtrate }\end{array}$ & $\begin{array}{l}\text { Living mytilid } \\
\text { shells }\end{array}$ & Concrete dock & ¿?? Dock & Steel dock & $\begin{array}{l}\text { Hull of stranded } \\
\text { ship }\end{array}$ & $\begin{array}{l}\text { Hull of stranded } \\
\text { ship }\end{array}$ \\
\hline Date & September, 2013 & September, 2013 & November,2013 & September, 2016 & December, 2016 & November, 2018 \\
\hline Latitude & $53^{\circ} 18^{\prime} 13.20^{\prime \prime S}$ & $53^{\circ} 10^{\prime} 14.02 \mathrm{~S}$ & $52^{\circ} 55^{\prime} 47.84^{\prime \prime} \mathrm{S}$ & $53^{\circ} 18^{\prime} 13.20^{\prime \prime S}$ & $54^{\circ} 56^{\prime} 06.10^{\prime \prime} \mathrm{S}$ & $53^{\circ} 06^{\prime} 23^{\prime \prime} \mathrm{S}$ \\
\hline Longitude & $70^{\circ} 26^{\prime} 05.14^{\prime \prime} \mathrm{W}$ & $70^{\circ} 54^{\prime} 21.16^{\prime \prime} \mathrm{W}$ & $70148^{\prime} 08.07 \mathrm{~W}$ & $70^{\circ} 26^{\prime} 05.14^{\prime \prime} \mathrm{W}$ & $67^{\circ} 37^{\prime} 05.20^{\prime \prime} \mathrm{W}$ & $70^{\circ} 52^{\prime} 42^{\prime \prime} \mathrm{W}$ \\
\hline $\begin{array}{l}\text { Depth range } \\
\text { (m) }\end{array}$ & $2-4$ & $3-5$ & 4 & 2 & $3-4$ & Intertidal \\
\hline Length (cm) & $2-6$ & 50 & $40-60$ & $30-240$ & $1-60$ & $15-80$ \\
\hline Weight (g) & $2-6$ & n.d. & n.d. & $188-440$ & $1-128$ & $20-100$ \\
\hline $\begin{array}{l}\text { Number of } \\
\text { colonies (N) }\end{array}$ & 18 & n.d. & n.d. & 8 & 7 & 91 \\
\hline \multirow[t]{2}{*}{ Shape } & Globular & Shape of drop & Shape of drop & $\begin{array}{c}\text { Shape of drop and } \\
\text { cylindrical }\end{array}$ & $\begin{array}{l}\text { Globular, drop and } \\
\text { cylindrical shape }\end{array}$ & $\begin{array}{l}\text { Mainly shape of } \\
\text { drop }\end{array}$ \\
\hline & 6.5 & 6.9 & 8.3 & 6.5 & 9.6 & 7.1 \\
\hline
\end{tabular}

shape could be affected by type (artificial or natural) and orientation of the substrate. Additionally, there is a positive, significant, linear relationship between size and weight of colonies, aspect not previously described in colonial ascidians (Table 1 ; Fig. 1 \& 2).

The discovery of giant colonial ascidians remain as unusual or striking fact (Ramos-Esplá \& Ocaña, 2017). Previous reports showing colonies of Eudistoma elongatum (Herdman, 1886), Distaplia cylindrica (Lesson, 1830) and Aplidium proliferum (Milne Edwards, 1841) attaining to 2.5 m lenght (Page \& Kelly, 2013; Ramos-Esplá \& Ocaña, 2017). Antarctic colonies of Distaplia cylindrica sized up $7 \mathrm{~m}$ (Kott, 1969). To our best knowledge, this finding in P. opuntia is one of the largest colonial ascidians reported in subantarctic waters.

In this study we found three morphological patterns in shallow waters (Fig. 1). The globular colonies living mainly on man-made and biological substrata such bivalves shells; the second and third type of colonies are fixed on most stable artificial substrata such as docks and hull of stranded ships. Thus, it is postulated that the colonial shape change with size (or age), stability and orientation of the substrate. To hypothesis level, is postulated that the shape of colonies could change seasonally.

In the present study, cylindrical colonies were collected in late winter and early spring in some Magellan locations. During this period low temperature prevails (Table 1 ). It is postulated that along winter the abundance of other colonial and solitary ascidians or predators could be reduced, helping to the growth in P. opuntia. High density of seawater under low temperature regime could favor the floatation of giant colonies in the water column (Barnes \& Clarke, 2011); Porvenir Bay is a shallow embayment ( $<12 \mathrm{~m}$ depth) and during winter sea surface temperature can attain to 1 to $2{ }^{\circ} \mathrm{C}$ (Cañete et al. 2014). Other reason could be that during winter and spring (July to November), the king crab boats remain in the fishing ground. No presence of boats in this period could reduce the opportunities of damage to the floating colonies of $P$. opuntia, allowing to attain largest size (Fig. 1e-f).

The weight-length relationship offer an opportunity to compare the differences in the fitting functions between solitary and colonial ascidians. For example, in Ciona intestinalis the fitting is an exponential function ( $\mathrm{W}=\mathrm{A} \times e^{-\mathrm{Br}}$; $\mathrm{Du} \mathrm{Clos}$ et al. 2017), while in P. opuntia show a linear fitting (Fig. 

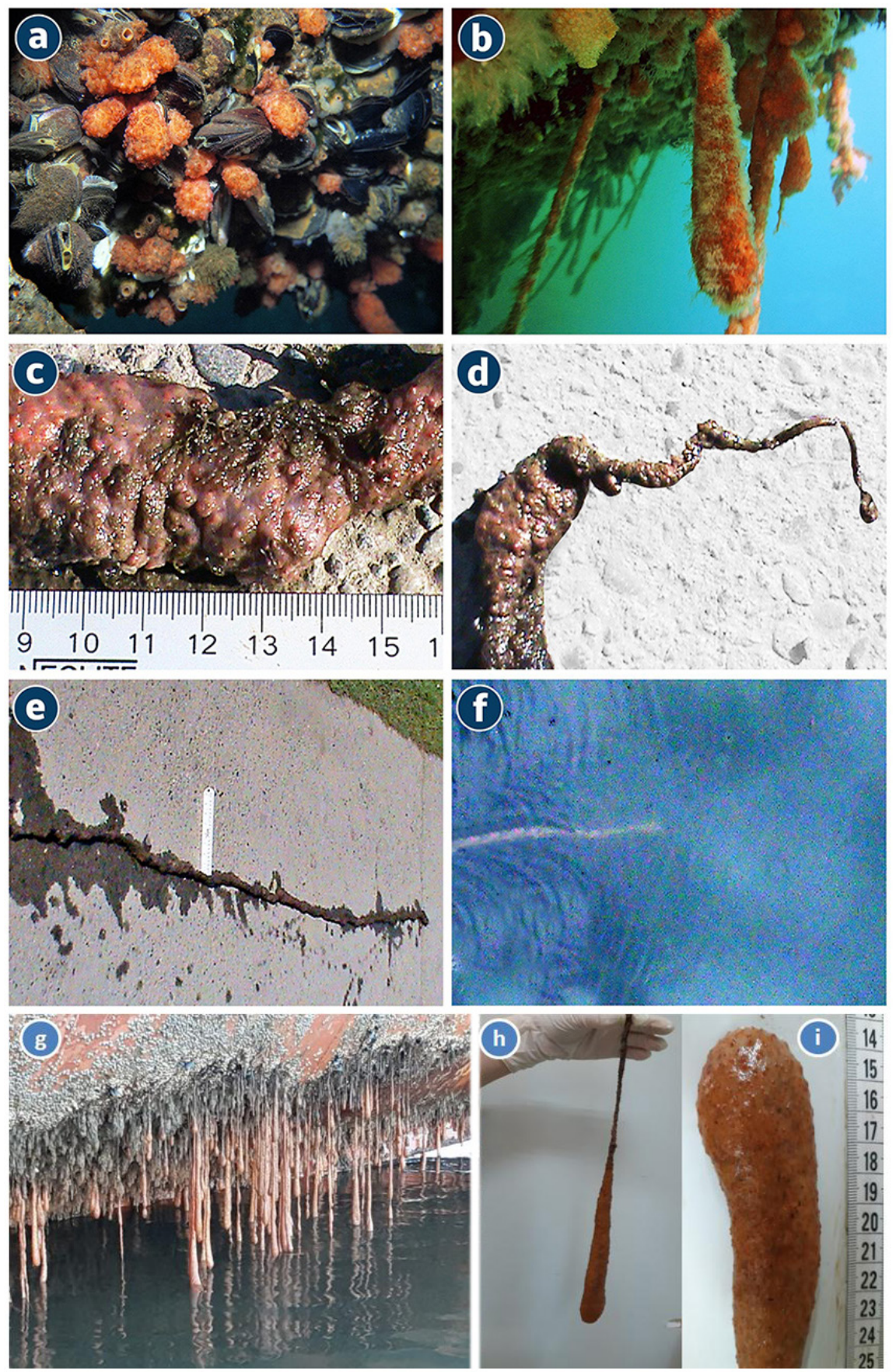

Fig. 1. Polyzoa opuntia: a) Fixation of globular colonies on the Mytilus chilensis shells suspended in the water column under Chilota dock, Porvenir Bay, Chile (September, 2013), Chile, b) Colonies with shape of drop under an old vessel hull off Puerto Williams, Navarino Island, Beagle Channel, Chile (December, 2016; $1.5 \mathrm{~m}$ depth), c) Detail of zooids in a section of the largest colony, d) shape of the colonial holdfast of the largest colony collected in this study (the length is nearly to $8 \mathrm{~cm}$ ), e) largest colony stretched on the floor to denote its extension (ruler have a length of $20 \mathrm{~cm}$; showed by black arrow), f) cylindrical colony suspended in the seawater, under Chilota dock, Porvenir Bay, Chile (September, 2016), g) Colonies with shape of drop fixed on stranded ship off Catalina Bay, Punta Arenas, Magellan Strait, Chile (November, 2018; intertidal), h) complete colony with detail of the length of peduncule and i) detail of the anterior end of a colony with drop shape, showing position of siphons (dark red spots). 


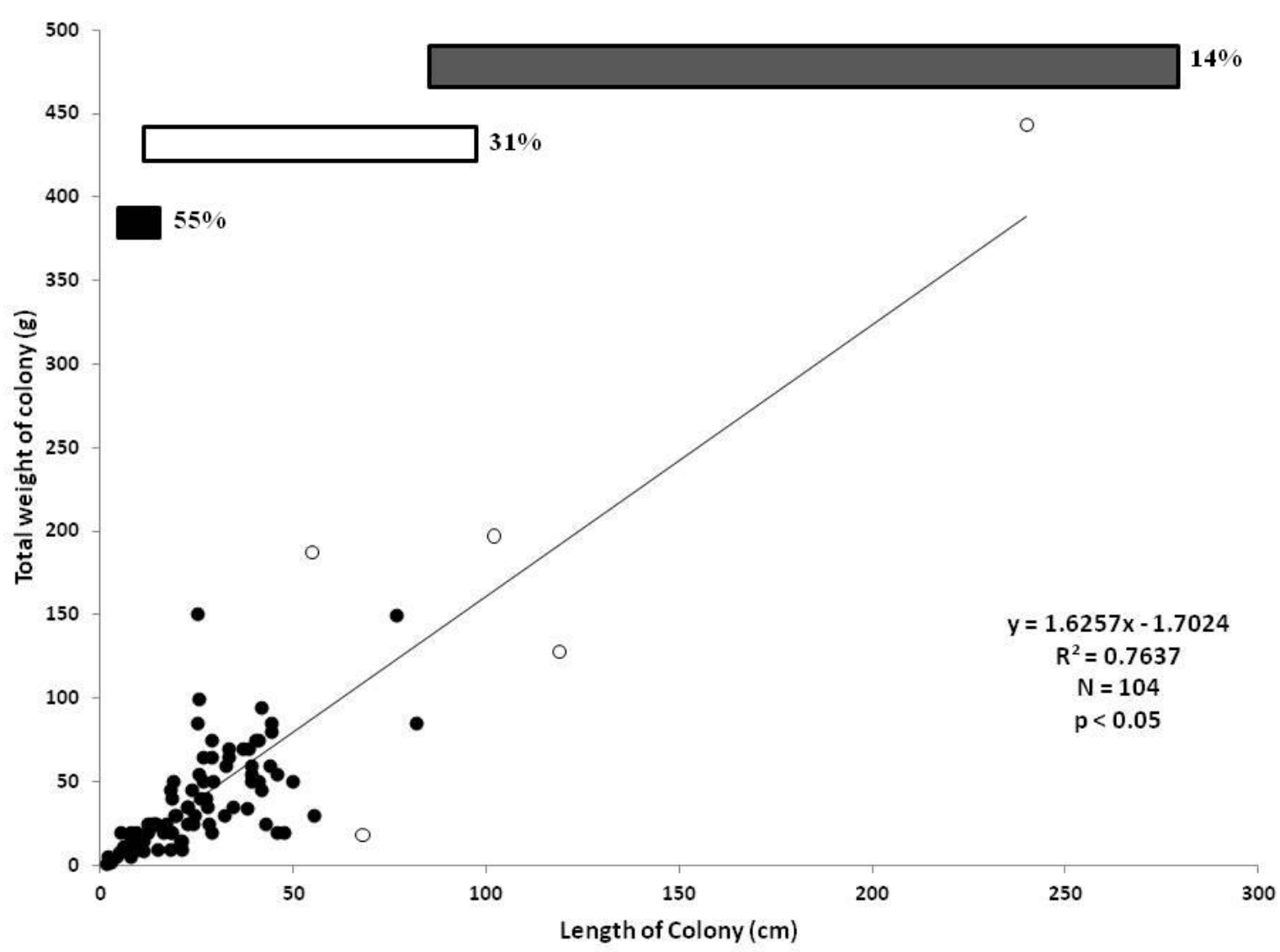

Fig. 2. Polyzoa opuntia. Length-weight relationship of colonies collected around Magellan Strait, Punta Arenas, Chile $(\bigcirc, 2016 \& 0,2018)$. Black rectangle indicate the range of size in globular colonies; white rectangle, the range of colonies with shape of drop; and gray rectangle, the range of length of cylindrical colonies. Percentages indicate the proportion of colonies in each morphological pattern.

2). No references to this length-weight relationship in colonial ascidians has been previously cited.

The fact of $P$. opuntia was found on mussel shells (Fig. 1 a) suggest a potential negative impact on bivalve aquaculture in southern Chile. However, low temperatures and salinities in shallow waters could limit the development of this colonial species (Turon et al. 2016a; Nagar \& Shenkar, 2016; De Castro et al. 2018) in estuarine zones available to aquaculture in Magellan waters.

The artificial substrates observed in this study shows that colonies of $P$. opuntia coexist with other colonial fouling species such Bugulalike bryozoans, colonial ascidians as Aplidium and hydrozoans, shaping a community based in a guild of clonal taxa. Large biomass of this guild could to produce a fast organic enrichment of the bottoms with tunicates of dead colonies. In the present study, the accumulated weight of colonies produced near to $4.5 \mathrm{~kg} \mathrm{~m}^{-2}(\mathrm{~N}=104)$.

The colonial size/shape in ascidians seem be regulated by exogenous (hydrodynamic, interespecific competition, primary production, and anthropogenic environmental disturbances), showing typical aspects associated to the clonal life cycle (Ramos-Esplá \& Ocaña, 2017). The large abundance, wide geographic distribution and the presence of giant colonies in P. opuntia suggest their potential use as biomodel to study the consequences of clonal life on the populational traits in a cold, estuarine system, where variable and extreme oceanographic conditions prevails (Jackson, 1977; Nakauchi, 1982; Caswell, 1985; Brown \& Swalla, 2012; Stolfi \& Brown, 2015).

$P$. opuntia is the only member of Stolidobranch colonial ascidian in Magellan waters. 
The rest belong mainly to Aplausobranch colonial ascidians (12 species: Distaplia colligans, D. cylindrica, Didemnum studeri, Trididemnum auriculatum, Polysincraton trivolutum, Aplidium fuegiense, A. magellanicum, A. variabile, A. falklandicum, Synoicum georgianum, Eudistoma magalhaensis and Sycozoa gaimardi) (Sanamyan \& Schories, 2003; Schories et al. 2015, Turon et al. 2016a \& b). This situation offer an interesting opportunity to compare the pattern of growth in colonial ascidians of cold and estuarine waters under a taxonomic perspective.

Additionally, the presence of $P$. opuntia in Subantarctic (Sanamyan \& Schories 2003, Sanamyan \& Schories, 2007; Lagger et al. 2009; Schories et al. 2015, Turon et al. 2016a \& b) and Antarctic waters (Kott, 1969; Monniot \& Monniot, 1983; Ramos-Esplá et al. 2005; Primo \& Vázquez, 2007) offer opportunities to study the comparative growth of colonies under two cold regimes.

\section{ACKNOWLEDGEMENTS}

The author thanks to the Direccion de Investigación y Postgrado, University of Magallanes, for this financial support of this project (Code: 026504). Special thanks go to the Bocas del Toro Station, Smithsonian Tropical Research Institute (STRI), which provided the opportunity to learn about the ecology and taxonomy of tropical ascidians during their 2011 PASI course and Dr. Xavier Turon (CSIC, Blanes, Spain) whom identified the Magellan species of ascidians during 2013 (CONICYT PAI MEC Folio 80122006). Special thank to Dra. Rosana M. Rocha (Universidade Federal do Paraná, Curitiba, Brasil) providing the recent reference of RamosEsplá \& Ocaña (2017).

\section{REFERENCES}

Barnes, D. K. A., \& Clarke, A. (2011). Antarctic marine biology. Current Biology, 21, 451457.

Biosecurity New Zealand (2007). Eudistoma elongatum. Australian drop tunicate. A type of sea squirt. Government of New Zealand, Factsheets.

Brown, F. D., \& Swalla, B. (2012). Evolution and development of budding by stem cells: ascidians coloniality as a case study. Developmental Biology, 369, 151-162.

Cañete, J. I., Aldea, C., \& Figueroa, T. (2014). Guía de identificación de la macrofauna bentónica de Bahía Porvenir, Chile. Punta Arenas: Editorial Universidad de Magallanes. Caswell, H. (1985). The evolutionary demography of clonal reproduction. In J. B. C. Jackson, L. W. Buss \& R. E. Cook (Eds.), Population biology and evolution of clonal organisms. (pp. 187-224). New Haven: Yale University Press.

De Castro, M. C. T., Vance, T., Yunnie, A. L. E., Fileman, T. W., \& Hall-Spencer, J. M. (2018). Low salinity as a biosecurity tool for minimizing biofouling on ship sea chests. Ocean Science, 14, 661-667.

Du Clos, K. T., Jones, I. T., Carrier, T. J., Brady, D. C., \& Jumars, P. A., (2017). Model-assisted measurements of suspension-feeding flow velocities. Journal of Experimental Biology, 220, 2096-2107.

Fuchs, J., Iseto, T., Hirose, M., Sundberg, P., \& Obst, M. (2010). The first internal molecular phylogeny of the animal phylum Entoprocta (Kamptozoa). Molecular Phylogenetic and Evolution, 56, 370-379.

Jackson, J. B. C. (1977). Competition on marine hard substrate: the adaptative significance of solitary and colonial strategies. American Naturalist, 111, 743-767.

Kott, P. (1969). Antarctic ascidiacea. Antarctic Research. Serie American Geophysical Union, Washington, DC, 13, 1-239.

Lagger, C., Häussermann, V., Försterra, G., \& Tatián, M. (2009). Ascidians from the southern Chilean Comau Fjord. Spixiana, 32, 173-185.

Millar, R. H. (1971). The biology of ascidians. Advances in Marine Biology, 9, 1-100.

Monniot, C., \& Monniot, F. (1983). Ascidies antarctiques et subantarctiques: morphologie et biogéographie. Éditions du Muséum (Ed.), Paris, Mémoires du Muséum National d'Histoire Naturelle, Zoologie, nouv. sér.

Monniot, C., Monniot, F. \& Laboute, P. (1991). Coral reef ascidians of New Caledonia. Orstom editions, Paris, 247 p. 
Nagar, L. R., \& Shenkar, N. (2016). Temperature and salinity sensitivity of the invasive ascidian Microcosmus exasperatus Heller, 1878. Aquatic Invasions, 11, 33-43.

Nakauchi, M. (1982). Asexual development of ascidians: its biological significance, diversity, and morphogenesis. American Zoologist, 22, 753-763.

Oyarzún, P. A., Toro, J. E., Cañete, J. I., \& Gardner, J. P. A. (2016). Bioinvasion threatens the genetic integrity of native diversity and a natural hybrid zone: smoothshelled blue mussels (Mytilus spp.) in the Strait of Magellan. Biological Journal of the Linnean Society, 117, 574-585.

Page, M. \& Kelly, M. (2013). Awesome ascidians. A guide to the sea squirts of New Zealand. Version 1. Produced for NIWA by TC Media Ltd, New Zealand.

Primo, C., \& Vázquez, E. (2007). Zoogeography of the Antarctic ascidian fauna in relation to the sub-Antarctic and South America. Antarctic Science, 19, 321-336.

Primo, C., \& Vázquez E. (2009). Antarctic ascidians: an isolated and homogeneous fauna. Polar Research, 28, 403-414.

Ramos-Esplá, A. A., \& Ocaña, O. (2017). A striking morphotype of Aplidium proliferum (Milne Edwards, 1841) (Ascidiacea: Polyclinidae) from the Strait of Gibraltar. Mediterranean Marine Science, 18, 156-160.

Ramos-Esplá A. A., Cárcel, J. A., \& Varela, M. (2005). Zoogeographical relationships of the littoral ascidiofauna at the Antarctic Peninsula, in the Scotia Arc and in the Magellan region. Scientia Marina, 69, 215-223.

Sanamyan, K. E., \& Schories, D. (2003). Ascidians from the Strait of Magellan. Aqua, Journal of Ichtyology and Aquatic Biology, 7, 8996.

Sanamyan, K., \& Schories, D. (2007). Redescription of Eudistoma magalhaensis (Michaelsen, 1907) (Ascidiacea) from Guaitecas Islands, Chile. Zootaxa, 1514, 65-68.

Schories, D., Sanamyan, K., Sanamyan, N., Díaz, M. J., Garrido, I., Heran, T., Holtheuer, J., \& Kohlberg, G. (2015). Geographic ranges of ascidians from Antarctica and the southeastern Pacific. Advances in Polar Science, 26, 8-23.

Shenkar N., Gittenberger, A., Lambert, G., Rius, M., Da Rocha, R. M., Swalla, B. J., \& Turon, X. (2017). Ascidiacea World Data base. Accessed at http://www.marinespecies. org/ascidiacea on 2017-12-03.

Stolfi, A., \& Brown, F.D. (2015). Tunicata. In: Evolutionary Developmental Biology of Invertebrates 6: Deuterostomia. Andreas Wanninger (Ed.), University of Vienna, Austria, Springer, Wien.

Tatián, M., \& Lagger, C. (2009). Ascidiacea - Ascidians. In V. Häussermann \& G. Försterra (Eds.), Marine Benthic Fauna of Chilean Patagonia (pp. 884-906). Puerto Montt: Nature in Focus.

Turon, X., Cañete, J. I., Sellanes, J., Rocha, R. M., \& López-Legentil, S. (2016a). Too cold for invasions? Contrasting patterns of native and introduced ascidians in subantarctic and temperate Chile. Management of Biological Invasions, 7, 77-86.

Turon, X., Cañete, J. I., Sellanes, J., Rocha, R. M. \& López-Legentil, S. (2016b). Ascidians fauna (Tunicata, Ascidiacea) of subantarctic and temperate regions of Chile. Zootaxa, 4093, 151-180. 